\title{
Non-metric characters in two species of Sotalia (Gray, 1866) (Cetacea, Delphinidae)
}

\author{
Fettuccia, DC. ${ }^{\text {a* }}$ da Silva, VMF. ${ }^{\text {a }}$ and Simões-Lopes, $P C{ }^{\text {b }}$ \\ ${ }^{a}$ Laboratório de Mamíferos Aquáticos - INPA, \\ Av. André Araújo, 2936, Aleixo, CEP 69060-001, Manaus, AM, Brazil \\ bLaboratório de Mamíferos Aquáticos - LAMAQ, Departamento de Ecologia e Zoologia, CCB, \\ Universidade Federal de Santa Catarina - UFSC, \\ CP 5102, CEP 88040-970, Florianópolis, SC, Brazil \\ *e-mail: fettuccia@hotmail.com
}

Received December 7, 2007 - Accepted August 27, 2008 - Distributed August 31, 2009

(With 12 figures)

\begin{abstract}
Analyses of non-metric characters of the skull and cervical vertebrae were performed among samples of dolphins of the genus Sotalia from the north, northeast and south Brazilian coast (S. guianensis) and also samples from the Amazon River Basin (S. fluviatilis) as part of an osteological descriptive study. The results demonstrated that there was a higher percentage of occurrence of fenestrae in the occipital region $(66 \%)$ and cervical ribs in the cervical vertebrae $(87 \%)$ in the riverine species. The vomer in wide shape was more frequent in the riverine species $(57 \%)$, followed by the intermediate (32\%) and narrow shape (11\%), that was found to be more frequent in the marine species $(66$ to $76 \%)$. In relation to the lacerate anterior foramen, it was observed that an open/elongated shape is more common in the riverine species (88\%). Most samples in the marine species present this foramen divided by a spike shaped projection (72 to 98\%). The ventrally visible location of the hypoglossal foramen was more often observed externally displaced in S. guianensis (88 to $98 \%$ ), while in S. fluviatilis, most samples (87\%) presented this foramen internally displaced to the jugular notch, and not visible in ventral view. The fluvial species seems to present neoteny (or maintenance of juvenile characters in adults) in relation to the position of the pterygoids and in development of lacerate anterior foramen.
\end{abstract}

Keywords: Morphology, Sotalia, osteology, skull, cervical vertebrae.

\section{Caracteres não métricos nas duas espécies de Sotalia (Gray, 1866)}

\section{Resumo}

Este é um trabalho osteológico descritivo entre exemplares do gênero Sotalia da costa Norte, Nordeste e Sul do Brasil e exemplares fluviais da bacia amazônica, analisando caracteres não métricos no crânio e nas vértebras cervicais. A frequência de ocorrência de fenestras na região occipital $(66 \%)$ e de costelas cervicais (87\%) foi maior na espécie fluvial (S. fluviatilis). Na espécie fluvial, a forma do vômer largo foi mais frequente (57\%), seguida da forma intermediária (32\%) e estreita (11\%). A forma do vômer estreito foi mais frequente na espécie marinha (S. guianensis) (66 a $76 \%$ ). Em relação ao forâmen lacerado anterior, foi observado que a forma aberta/alongada é mais comum na espécie fluvial (88\%). Na espécie marinha, a maioria dos exemplares apresenta este forâmen dividido por uma projeção em forma de espinho (72 a 98\%). A localização do forâmen hipoglossal visível ventralmente foi mais observada em S. guianensis (88 a 98\%), enquanto que em S. fluviatilis, a maioria dos exemplares (87\%) apresentou este forâmen deslocado internamente à reentrância jugular, não podendo ser observado em vista ventral. A espécie fluvial parece apresentar neotenia (ou manutenção de caracteres juvenis no adulto) em relação ao posicionamento dos pterigoides e ao desenvolvimento do forâmen lacerado interior.

Palavras-chave: morfologia, Sotalia, osteologia, crânio, vértebra cervical.

\section{Introduction}

The genus Sotalia (Gray, 1866) was until recently considered monospecific, however recent molecular genetics (Cunha et al., 2005; Caballero et al., 2007), and geometric morphometric (Monteiro-Filho et al., 2002)

studies revealed the existence of two species: the marine species Sotalia guianensis (P.J. van Bénéden, 1864) (gray dolphin) and the riverine species Sotalia fluviatilis (Gervais, 1853) (tucuxi). 
The marine species is broadly distributed along the tropical and subtropical Atlantic coast of South and Central America, having been recorded from Florianópolis, Santa Catarina, Brazil $\left(27^{\circ} 35^{\prime} \mathrm{S}\right.$ and $48^{\circ} 34^{\prime} \mathrm{W}$ ) (SimõesLopes, 1988; Borobia, 1989) to Honduras (15 $58^{\prime} \mathrm{N}$ and $85^{\circ} 42^{\prime}$ W) (da Silva and Best, 1996). The riverine species is endemic to the Amazon Basin, occurring from Belém (at the mouth of the Amazon River), in Brazil, to the rivers of Peru, Colombia and Ecuador (Borobia et al., 1991, da Silva and Best, 1996).

Osteological descriptions for the genus Sotalia have been published by Miranda-Ribeiro (1936); Casinos et al. (1981); Borobia (1989); Menezes and SimõesLopes (1996); da Silva and Best (1996); Alves Júnior and Monteiro-Neto (1999); Avila et al. (2002); Fettuccia and Simões-Lopes (2004), Simões-Lopes (2006). With the exception of Simões-Lopes (2006), these studies were mainly based on traditional studies of morphometrics. There are no previous comparative studies using non-metric characteristics such as, for example, the com- parison of forms or presence and absence of determined characters for this genus. Therefore, this study aims to compare the two species of the genus Sotalia using nonmetric characters.

\section{Material and Methods}

A total of 149 specimens were analysed from five distinct Brazilian states: Mammal Collection of National Institute for Amazônia Research (INPA), Manaus, Amazonas (AM); Emilio Goeldi Museum (MPEG), Belém, Pará (PA); Aquatic Mammals Laboratory (LMA) of the Department of Ecology and Zoology, Federal University of Santa Catarina (UFSC), Florianópolis, Santa Catarina (SC); as well as the Osteological Archive of the Association of Research and Preservation of Aquatic Ecosystems (AQUASIS), Caucaia, Ceará (CE) (Tables 1-4). The INPA collection contains riverine specimens (S. fluviatilis) from the Amazonas State (AM), marine specimens from the coast of the Amapá (AP) and es-

Table 1. List of Sotalia fluviatilis analysed from the northern region (Amazon State, Brazil), deposited at INPA's mammals collection. $\mathrm{F}$ - female, $\mathrm{M}$ - male, $\mathrm{I}$ - indeterminate gender. $\mathrm{N}=44$

\begin{tabular}{|c|c|c|c|c|c|c|c|}
\hline $\begin{array}{c}\text { Collection } \\
\text { number }\end{array}$ & Sex & $\begin{array}{l}\text { Age } \\
\text { class }\end{array}$ & Locality & $\begin{array}{c}\text { Collection } \\
\text { number }\end{array}$ & Sex & $\begin{array}{l}\text { Age } \\
\text { class }\end{array}$ & Locality \\
\hline INPA 005 & I & adult & Japurá River & INPA 054 & M & calf & Amazonas River \\
\hline INPA 007 & I & adult & Tefé Lake & INPA 055 & I & adult & Amazonas River \\
\hline INPA 008 & I & adult & Tefé Lake & INPA 056 & $\mathrm{~F}$ & adult & Amazonas River \\
\hline INPA 009 & M & juvenile & Negro River & INPA 057 & $\mathrm{~F}$ & adult & Amazonas River \\
\hline INPA 015 & $\mathrm{~F}$ & calf & Japurá River & INPA 059 & M & juvenile & $\begin{array}{l}\text { Marchantaria, } \\
\text { Solimões River }\end{array}$ \\
\hline INPA 016 & I & adult & Japurá River & INPA 060 & M & juvenile & $\begin{array}{l}\text { Marchantaria, } \\
\text { Solimões River }\end{array}$ \\
\hline INPA 017 & M & adult & Japurá River & INPA 062 & $\mathrm{~F}$ & adult & Tefé Lake \\
\hline INPA 018 & I & calf & Japurá River & INPA 065 & M & calf & Japurá River \\
\hline INPA 020 & I & adult & Japurá River & INPA 067 & I & adult & Japurá River \\
\hline INPA 024 & I & adult & Japurá River & INPA 069 & $\mathrm{~F}$ & adult & $\begin{array}{l}\text { Negro River/ } \\
\text { Anavilhanas }\end{array}$ \\
\hline INPA 026 & M & juvenile & Purus River & INPA 071 & $\mathrm{~F}$ & adult & Japurá River \\
\hline INPA 029 & $\mathrm{~F}$ & juvenile & Tefé Lake & INPA 072 & I & adult & Pará River \\
\hline INPA 038 & $\mathrm{~F}$ & calf & Japurá River & INPA 073 & $\mathrm{~F}$ & adult & Purus River \\
\hline INPA 039 & M & immature & Japurá River & INPA 074 & M & adult & Purus River \\
\hline INPA 040 & $\mathrm{~F}$ & adult & Amanã Lake & INPA 080 & M & calf & $\begin{array}{l}\text { Catalão, Negro } \\
\text { River }\end{array}$ \\
\hline INPA 041 & M & adult & $\begin{array}{l}\text { Negro River/ } \\
\text { Anavilhanas }\end{array}$ & INPA 081 & M & juvenile & $\begin{array}{l}\text { Cabaliana Lake, } \\
\text { Manacapuru }\end{array}$ \\
\hline INPA 043 & M & juvenile & Japurá River & INPA 082 & $\mathrm{~F}$ & calf & Tapajós River \\
\hline INPA 047 & M & adult & Juruá River & INPA 093 & M & adult & $\begin{array}{l}\text { Tocantis River/ } \\
\text { Tucuruí }\end{array}$ \\
\hline INPA 050 & $\mathrm{~F}$ & immature & Amanã Lake & INPA 097 & $\mathrm{~F}$ & juvenile & Negro River \\
\hline INPA 051 & M & calf & Amazonas River & INPA 113 & M & adult & Solimões River \\
\hline INPA 052 & M & adult & Amazonas River & INPA 149 & I & adult & Coari Grande River \\
\hline INPA 053 & $\mathrm{~F}$ & adult & Amazonas River & INPA 151 & I & adult & Coari Grande River \\
\hline
\end{tabular}


Table 2. List of Sotalia guianensis analyzed from northern region (Amapá and Pará States, Brazil), deposited at INPA and MPEG mammals collections, respectively. F - female, M - male, I - indefinite gender. $\mathrm{N}=26$.

\begin{tabular}{ccclcccc}
\hline $\begin{array}{c}\text { Collection } \\
\text { number }\end{array}$ & Sex & $\begin{array}{c}\text { Age } \\
\text { class }\end{array}$ & \multicolumn{1}{c}{ Locality } & $\begin{array}{c}\text { Collection } \\
\text { number }\end{array}$ & Sex & $\begin{array}{c}\text { Age } \\
\text { class }\end{array}$ & Locality \\
\hline INPA 120 & M & juvenile & Amazonas Estuary & INPA 133 & M & juvenile & North of Amapá \\
INPA 121 & M & juvenile & Amazonas Estuary & INPA 134 & F & adult & North of Amapá \\
INPA 122 & M & juvenile & Amazonas Estuary & INPA 135 & F & calf & North of Amapá \\
INPA 123 & M & adult & North of Amapá & INPA 136 & M & calf & North of Amapá \\
INPA 124 & F & juvenile & North of Amapá & INPA 137 & M & calf & North of Amapá \\
INPA 125 & F & juvenile & Amazonas Estuary & INPA 138 & F & juvenile & North of Amapá \\
INPA 126 & M & juvenile & North of Amapá & INPA 139 & F & juvenile & North of Amapá \\
INPA 127 & M & calf & North of Amapá & INPA 140 & M & juvenile & North of Amapá \\
INPA 128 & M & calf & North of Amapá & INPA 141 & F & adult & North of Amapá \\
INPA 129 & M & adult & North of Amapá & INPA 142 & F & adult & North of Amapá \\
INPA 130 & $\mathrm{F}$ & juvenile & North of Amapá & INPA 143 & F & adult & North of Amapá \\
INPA 131 & $\mathrm{F}$ & calf & Amazonas Estuary & MPEG 24548 & I & adult & Marajó Island \\
INPA 132 & $\mathrm{F}$ & calf & Amazonas Estuary & MPEG 10945 & $\mathrm{F}$ & juvenile & Marajó Island \\
\hline
\end{tabular}

Table 3. List of Sotalia guianensis analysed from the Northeast region (Ceará state, Brazil), deposited at AQUASIS's collection. $\mathrm{F}$ - female, $\mathrm{M}$ - male, I - indeterminate gender. $\mathrm{N}=41$.

\begin{tabular}{|c|c|c|c|c|c|c|c|}
\hline $\begin{array}{c}\text { Collection } \\
\text { number }\end{array}$ & Sex & Age class & Locality & $\begin{array}{c}\text { Collection } \\
\text { number }\end{array}$ & Sex & $\begin{array}{l}\text { Age } \\
\text { class }\end{array}$ & Locality \\
\hline Aq 002 & M & adult & Caucaia & Aq 210 & $\mathrm{~F}$ & adult & Paracuru \\
\hline Aq 004 & I & juvenile & Fortaleza & Aq 212 & $\mathrm{~F}$ & adult & Fortaleza \\
\hline Aq 012 & I & adult & Fortaleza & Aq 213 & M & calf & Fortaleza \\
\hline Aq 013 & M & adult & Fortaleza & Aq 214 & $\mathrm{~F}$ & juvenile & Caucaia \\
\hline Aq 023 & M & adult & Caucaia & Aq 215 & I & adult & São G. Amarante \\
\hline Aq 026 & I & adult & Caucaia & Aq 218 & $\mathrm{M}$ & juvenile & São G. Amarante \\
\hline Aq 036 & $\mathrm{~F}$ & adult & Fortaleza & Aq 222 & $\mathrm{~F}$ & adult & Fortaleza \\
\hline Aq 038 & M & adult & Caucaia & Aq 231 & M & adult & Caucaia \\
\hline Aq 039 & I & adult & São G. Amarante & Aq 232 & M & adult & Fortaleza \\
\hline Aq 040 & I & calf & São G. Amarante & Aq 234 & M & adult & Caucaia \\
\hline Aq 041 & I & immature & Fortaleza & Aq 236 & I & adult & São G. Amarante \\
\hline Aq 042 & M & adult & Fortaleza & Aq 239 & M & adult & Fortaleza \\
\hline Aq 058 & $\mathrm{~F}$ & adult & Fortaleza & Aq 240 & I & immature & Paraipaba \\
\hline Aq 071 & I & adult & Cascavel & Aq 241 & I & adult & Caucaia \\
\hline Aq 084 & M & adult & Fortaleza & Aq 247 & $\mathrm{~F}$ & adult & Fortaleza \\
\hline Aq 132 & M & juvenile & São G. Amarante & Aq 250 & $\mathrm{M}$ & calf & Paraipaba \\
\hline Aq 134 & M & adult & Fortaleza & Aq 251 & I & adult & Trairé \\
\hline Aq 139 & I & adult & Itapipoca & Aq 253 & $\mathrm{M}$ & adult & Fortaleza \\
\hline Aq 159 & I & adult & Fortaleza & Aq 259 & $\mathrm{M}$ & adult & Fortaleza \\
\hline Aq 184 & $\mathrm{~F}$ & adult & Fortaleza & Aq 262 & I & adult & Bitupitá \\
\hline Aq 196 & I & immature & São G. Amarante & - & - & - & - \\
\hline
\end{tabular}

tuarine specimens (S. guianensis) from Pará State (PA). The other collections only possess marine specimens from their respective localities. Forty-four specimens of S. fluviatilis and 105 specimens of S. guianensis were analyzed $(\mathrm{AP}=24 ; \mathrm{PA}=02 ; \mathrm{CE}=41 ; \mathrm{SC}=38)$. The marine specimens were divided into 3 large areas: NOR (including specimens from AP and PA), for the specimens from the coast of Amapá and Pará States, CE for 
Table 4. List of Sotalia guianensis analysed from the Southern region (Santa Catarina state, Brazil), deposited at LAMAq's collection (UFSC). F - female, M - male, I - indeterminate gender. $\mathrm{N}=38$.

\begin{tabular}{|c|c|c|c|c|c|c|c|}
\hline $\begin{array}{c}\text { Collection } \\
\text { number }\end{array}$ & Sex & $\begin{array}{l}\text { Age } \\
\text { class }\end{array}$ & Locality & $\begin{array}{c}\text { Collection } \\
\text { number }\end{array}$ & Sex & $\begin{array}{l}\begin{array}{c}\text { Age } \\
\text { class }\end{array} \\
\end{array}$ & Locality \\
\hline UFSC1010 & I & juvenile & Daniela Beach & UFSC1222 & $\mathrm{M}$ & immature & Estreito \\
\hline UFSC1073 & I & adult & Biguaçu & UFSC1223 & M & calf & Anhatomirim Island \\
\hline UFSC1079 & $\mathrm{F}$ & adult & Beira Mar Norte & UFSC1226 & $\mathrm{M}$ & adult & G. Celso Ramos \\
\hline UFSC1082 & I & adult & Beira Mar Norte & UFSC1236 & $\mathrm{F}$ & calf & Sambaqui \\
\hline UFSC1083 & $\mathrm{M}$ & adult & Beira Mar Norte & UFSC1245 & I & juvenile & São F. do Sul \\
\hline UFSC1104 & $\mathrm{F}$ & immature & Beira Mar Norte & UFSC1247 & I & adult & Cacupé \\
\hline UFSC1108 & $\mathrm{M}$ & adult & Beira Mar Norte & UFSC1253 & $\mathrm{M}$ & juvenile & Beira Mar Norte \\
\hline UFSC1117 & I & adult & Biguaçu & UFSC1266 & $\mathrm{M}$ & immature & Biguaçu \\
\hline UFSC1130 & $\mathrm{F}$ & adult & G. Celso Ramos & UFSC1268 & $\mathrm{F}$ & adult & Biguaçu \\
\hline UFSC1174 & M & calf & Sambaqui & UFSC1289 & $\mathrm{F}$ & adult & G. Celso Ramos \\
\hline UFSC1175 & $\mathrm{M}$ & adult & São F. do Sul & UFSC1291 & $\mathrm{M}$ & adult & G. Celso Ramos \\
\hline UFSC1176 & I & adult & Costeira & UFSC1296 & $\mathrm{M}$ & juvenile & Anhatomirim \\
\hline UFSC1178 & $\mathrm{M}$ & juvenile & Sambaqui & UFSC1297 & $\mathrm{M}$ & adult & G. Celso Ramos \\
\hline UFSC1179 & M & juvenile & Beira Mar Norte & UFSC1302 & I & adult & Itapoá \\
\hline UFSC1180 & $\mathrm{F}$ & adult & Cacupé & UFSC1307 & $\mathrm{M}$ & juvenile & Daniela Beach \\
\hline UFSC1203 & $\mathrm{F}$ & adult & Anhatomirim & UFSC1311 & I & immature & São F. do Sul \\
\hline UFSC1208 & $\mathrm{F}$ & adult & Estreito & UFSC1312 & $\mathrm{M}$ & adult & Estreito \\
\hline UFSC1218 & $\mathrm{F}$ & adult & Curtume Beach & UFSC1321 & $\mathrm{F}$ & adult & Itaguaçu Beach \\
\hline UFSC1219 & $\mathrm{F}$ & adult & Costeira & UFSC1327 & $\mathrm{M}$ & calf & Beira Mar Norte \\
\hline
\end{tabular}
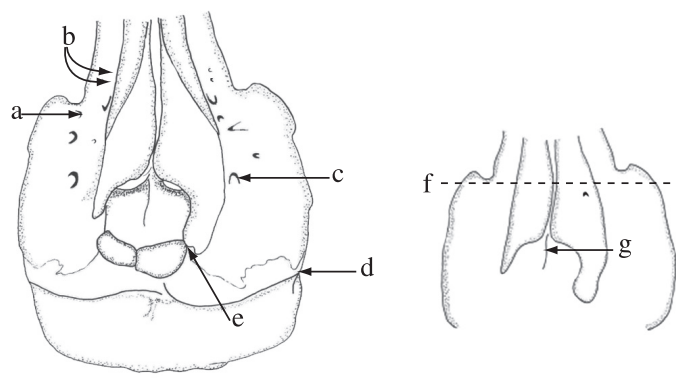

Figure 1. Scheme of Delphinidae skull in dorsal view, showing non-metric characters: a) Asymmetry of position of the two anterior most large maxillary foramina; b) Number of small foramina in the maxillary; c) Number of foramina in the maxillary behind a line at the level of the anterior edge of the external nares; d) Contact between maxillary and occipital; e) Contact between premaxillary and nasal, on right side; f) Asymmetry of position of the two premaxillary foramina; and g) Development of dorsal mesethmoid spine at the anterior margin of external nares. Adapted from Perrin et al. (1982).
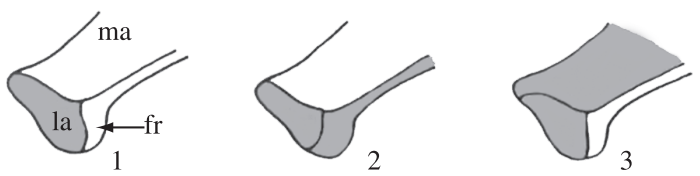

Figure 2. Composition of the anteorbital process, in lateral view, of the left side: 1) formed by lacrimal; 2) formed by lacrimal and frontal; 3) formed by lacrimal and maxillary. la: lacrimal; ma: maxilar; fr: frontal. Adapted from Perrin et al. (1982).

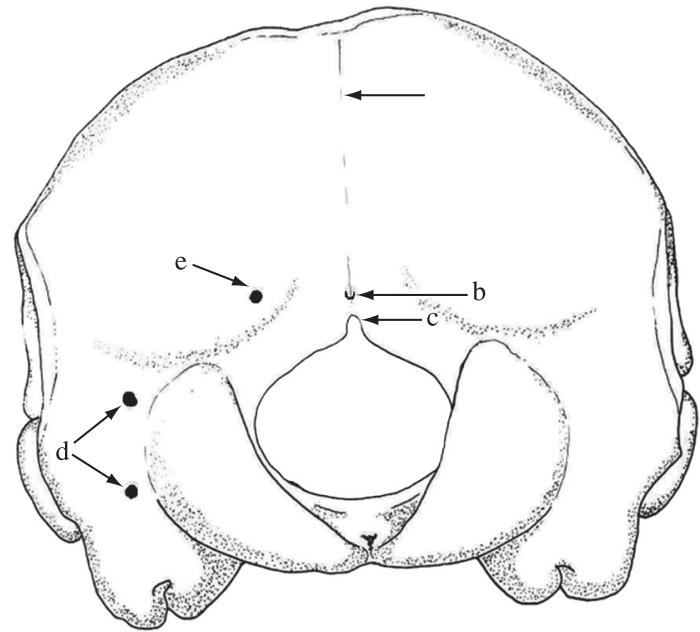

Figure 3. Scheme of Delphinidae skull in posterior view, showing non-metric characters: a) Medial occipital ridge, projecting above level of the occipital swellings at midheigh; b) Accessory foramen above foramen magnum; c) Clear notch in upper margin of foramen magnum; d) Number of fenestrations in occipital, near foramen magnum and in exoccipital region; e) Number of fenestrations in occipital swellings region. Adapted from Perrin et al. (1982).

the specimens off the Ceará coast and SC for specimens from the Santa Catarina coast.

The skulls were compared using non-metric characters, in accordance with Perrin et al. (1982) and two newly proposed characters (Table 5; Figures 1-4). The 
Table 5. List of non-metric characters analysed in skulls and cervical vertebrae from specimens of the genus Sotalia. Adapted from Perrin et al. (1982) and two new proposed characters (4a e 4g). NI: not illustrated.

\section{Figure character and character condition}

1 a. Asymmetry of position of the two anterior most large maxillary foramina: 1- symmetrical; 2- left foramen more anteriorly placed; right foramen more anterior.

b. Number of small foramina in the maxillary anterior to the anterior-most of the three large foramina.

c. Number of foramina in the maxillary behind a line at the level of the anterior edge of the external nares and perpendicular to the long axis of the skull.

d. Contact between maxillary and occipital, at point where occipital crest intersects margin of temporal fossa: 1- contact (or space of $<1 \mathrm{~mm}$ ); 2- no contact.

e. Contact between premaxillary and nasal, on right side: 1 - contact (or space of <1 mm); 2- no contact.

f. Asymmetry of position of the two premaxillary foramina: 1- symmetrical; 2- left foramen more anteriorly placed; right foramen more anterior

g. Development of dorsal mesethmoid spine at the anterior margin of external nares, between angles of premaxillaries: 1- elevation of the ossified portion of the mesethmoid to, or near to the level of the dorsal surfaces of the premaxillaries; 2- no such elevation.

2 Composition of the anteorbital process, in lateral view, of the left side: 1- formed by lacrimal; 2- formed by lacrimal and frontal; 3- formed lacrimal and maxillary.

3 a. Medial occipital ridge, projecting above level of the occipital swellings at mid-height: 1- present;

2- absent, or not projecting above swellings.

b. Accessory foramen above foramen magnum: 1- present; 2- absent.

c. Clear notch in upper margin of foramen magnum: 1- present; 2- absent.

d. Number of fenestrations in occipital, near foramen magnum and in exoccipital region. e. Number of fenestrations in region of occipital swellings.

4 a. Shape of the vomer among posterior process of the pterygoids: 1 - wide; 2- intermediate; 3- narrow.

b. Anterior contact between pterygoid hamuli: 1- open (gap $>1 \mathrm{~mm}$ ); 2- closed.

b. Posterior contact between pterygoid hamuli: 1- open (gap $>1 \mathrm{~mm}$ ); 2- closed.

$\mathrm{d}$. Shape of posterior projection of left pterygoid hamulus: 1- longer than wide $(\mathrm{y}>\mathrm{x})$; 2- wider than long, or equal $(\mathrm{x}>\mathrm{y})$.

e- Vomer's posterior alignment in relation to pterygoids's lamellar process: 1- anterior; 2- aligned;

3- posterior.

$\mathrm{f}$ - Number of fenestrations in region of basoccipital.

g- Shape of the anterior lacerate foramen (right): 1- open; 2- with projection spine form; 3- narrow.

$\mathrm{h}$ - Visibility, in ventro-occipital view of mesially directed hypogossal foramen between basoccipital and exoccipital process (jugular notch): 1- visible; 2 - not visible.

NI Cervical rib: 1- present; 2 - absent.

cervical vertebrae were analyzed according to the presence or absence of cervical ribs.

In order to observe ontogenetic variation, the characters were evaluated by age classes (calf, juvenile, immature and adult) (adapted from Dawbin et al., 1970). Variations between the sexes were not analysed in this study due to the small sample size.

The terminology used for skeletal bones followed Flower (1885), Kraglievich (1937), Lessertieur and Saban (1967), Rommel (1990) and Simões-Lopes (2006).

\section{Results}

Of the 22 non-metric characters analysed, only six were informative for the distinction between the two species.

\subsection{Fenestrae}

A high frequency of fenestrae in the occipital region was observed, near the foramen magnum in S. fluviatilis (66\%; n = 44). In $S$. guianensis the percentage of occurrence of fenestrae varied between $31 \%$ (specimens from NOR, $\mathrm{n}=26), 10 \%(\mathrm{CE}, \mathrm{n}=41)$ and $13 \%(\mathrm{SC}$, $\mathrm{n}=39$ ).

The number of fenestrae near the condyle was also larger in the riverine species, varying from one to four per individual. In both species, these structures were found in all age classes.

In the marine species, the specimens from $\mathrm{CE}$ and NOR exhibited one to three fenestrae, while those from SC exhibited only one to two. Fenestrae can occur only on one side (more common in the marine species) or on 

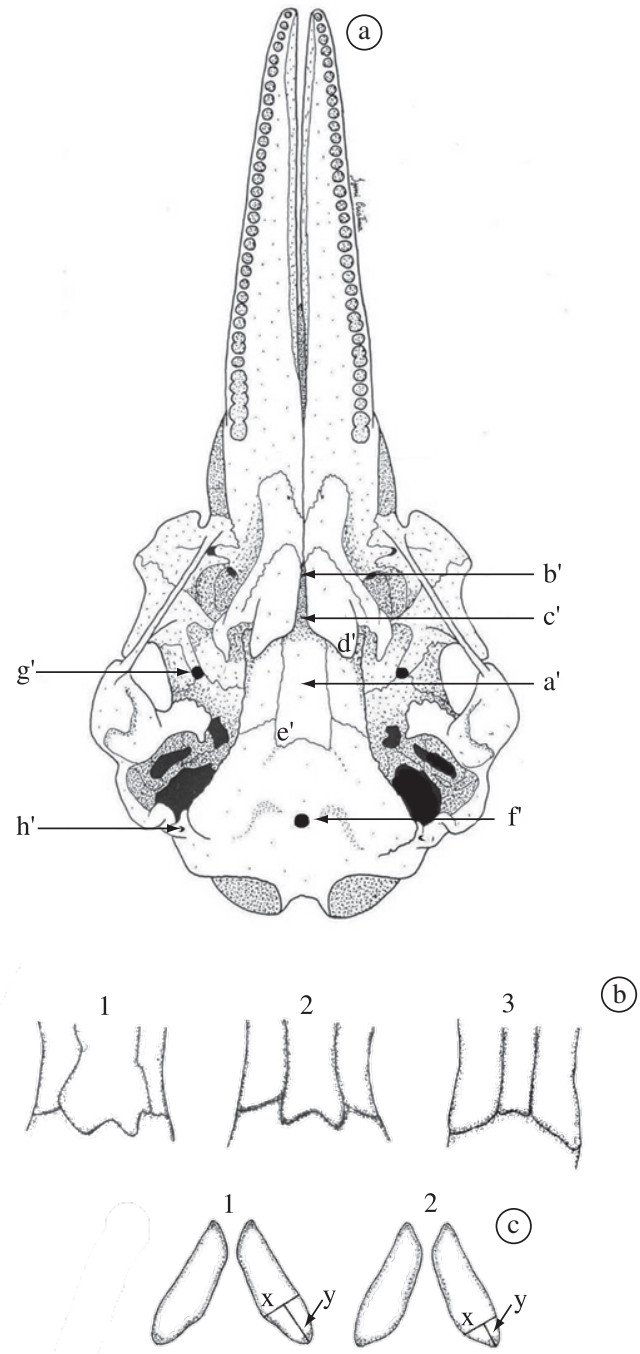

(d)

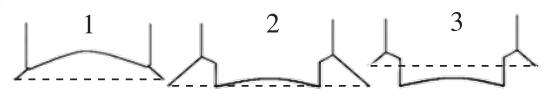

Figure 4. a) Skull of Sotalia fluviatilis in ventral view, showing non-metric characters (adapted from Perrin et al., 1982): a') shape of the vomer among posterior process of the pterygoids: 1) wide; 2) intermediate; 3) narrow; b') anterior contact between pterygoid hamuli; c') posterior contact between pterygoid hamuli; d') shape of posterior projection of left pterygoid hamulus: 1) longer than wide $(y>x)$; 2) wider than long, or equal ( $x>y)$; e') vomer's posterior alignment in relation to pterygoids's lamellar process: 1) anterior; 2) aligned; 3) posterior; f') number of fenestrations in basoccipital region; g') Shape of the anterior lacerate foramen (right); h') visibility, in ventro-occipital view of mesially directed hypogossal foramen between basoccipital and exoccipital process (jugular notch). b) Detail of vomer shape (character a'); c) Detail of hamular process shape from left pterygoide (character d'); d) Detail of alignment from posterior border of vomer (character e'). Skull design from Izeni P. Farias. both sides of the occipital condyle (more common in the riverine species). In newborn and young specimens, other openings in the occipital region (located above the fenestrae) were observed, corresponding to the fontanelles, formed by the union of the exoccipital, parietal and supraoccipital bones (Figure 5).

In the region of occipital protuberance, in general, the occurrence of fenestrae was less frequent: $4.5 \%$ in S. fluviatilis $(\mathrm{n}=44), 10 \%$ for $S$. guianensis of CE ( $\mathrm{n}=41), 5 \%$ for specimens from $\mathrm{SC}(\mathrm{n}=38)$ and no occurrence for marine specimens from NOR $(n=26)$. In some specimens of the two species, small fenestrae of irregular contour in the basioccipital were observed. In the marine species, such fenestrae occurred in $2 \%$ $(n=41)$ and $8 \%(n=39)$ of the specimens from CE and
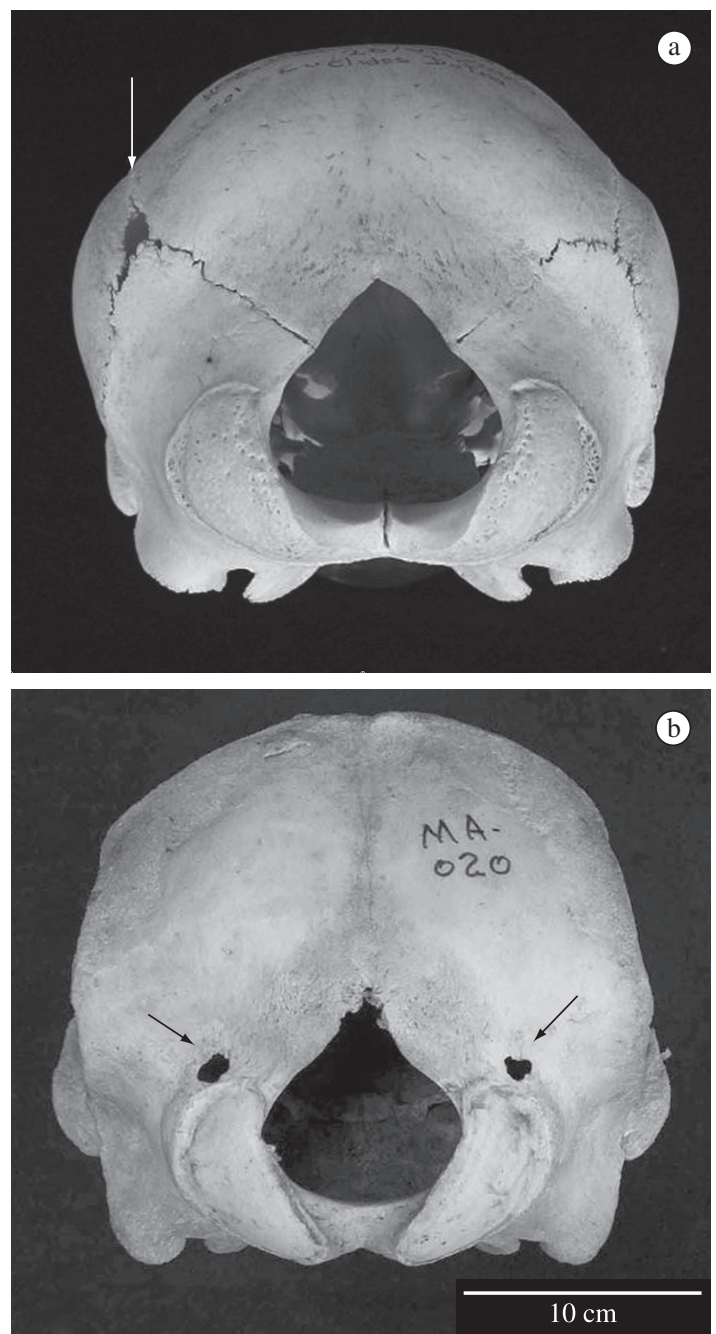

Figure 5. Skull of Sotalia in posterior view. a) Calf of S. guianensis (SC), indicating the sutures (black arrows) and fontanelles (white arrow) in occipital area. b) Adult of S. fluviatilis (AM), indicating the fenestras next from condile occipital (black arrows). In the calf skull the fenestras are located below the sutures of occipital area. 

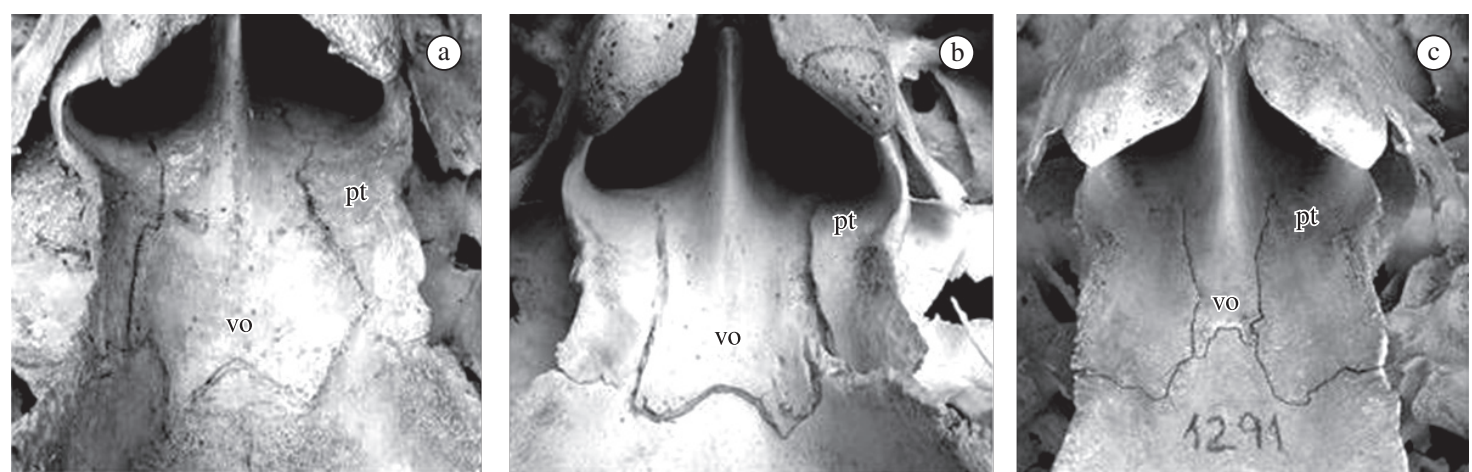

Figure 6. Shapes of the vomer observed in the genus Sotalia: a) wide; b) intermediate; and c) narrow. vo: vomer, pt: posterior process of pterygoide.

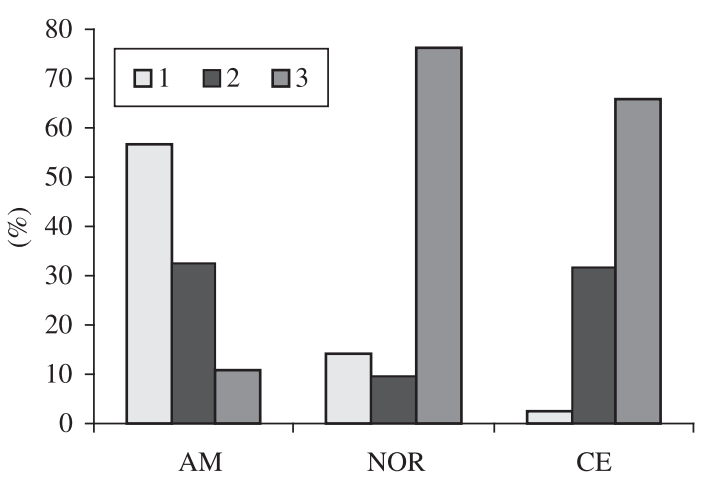

Figure 7. Variation of the vomer shapes in the genus Sotalia: 1- wide; 2- intermediate; 3- narrow. AM- Amazonas, CECeará, NOR (samples from AP and PA together).

$\mathrm{SC}$, respectively. In the riverine species, these fenestrae occurred in $9 \%(n=43)$ of the specimens. These openings were not observed in the marine specimens from NOR.

\subsection{Vomer}

There was a prevalence of one form of vomer for the marine species, and another form for the riverine species (Figure 6). The wide form (wider in the posterior region) was more frequent in the riverine species, occurring in $57 \%(\mathrm{n}=37)$ of specimens, followed by the intermediate form $(32 \%)$ and the narrow form $(11 \%)$ (Figure 7$)$. In the marine species, the narrow form was most frequent, occurring in $76 \%(\mathrm{n}=21)$ of the specimens from NOR and in $66 \%(\mathrm{n}=38)$ of the specimens from CE. The intermediate form of the vomer occurred in $9.5 \%(n=21)$ of the specimens from NOR and in $31.5 \%(n=38)$ of the specimens from CE. This characteristic was added later to the analysis, thus the specimens from SC were not included in the analyses. This characteristic seems to be related with individual variation and not with development.

\subsection{Pterygoids}

The contact, anterior and posterior, between pterygoids exhibited no variation, being separate (gap $>1 \mathrm{~mm}$ )
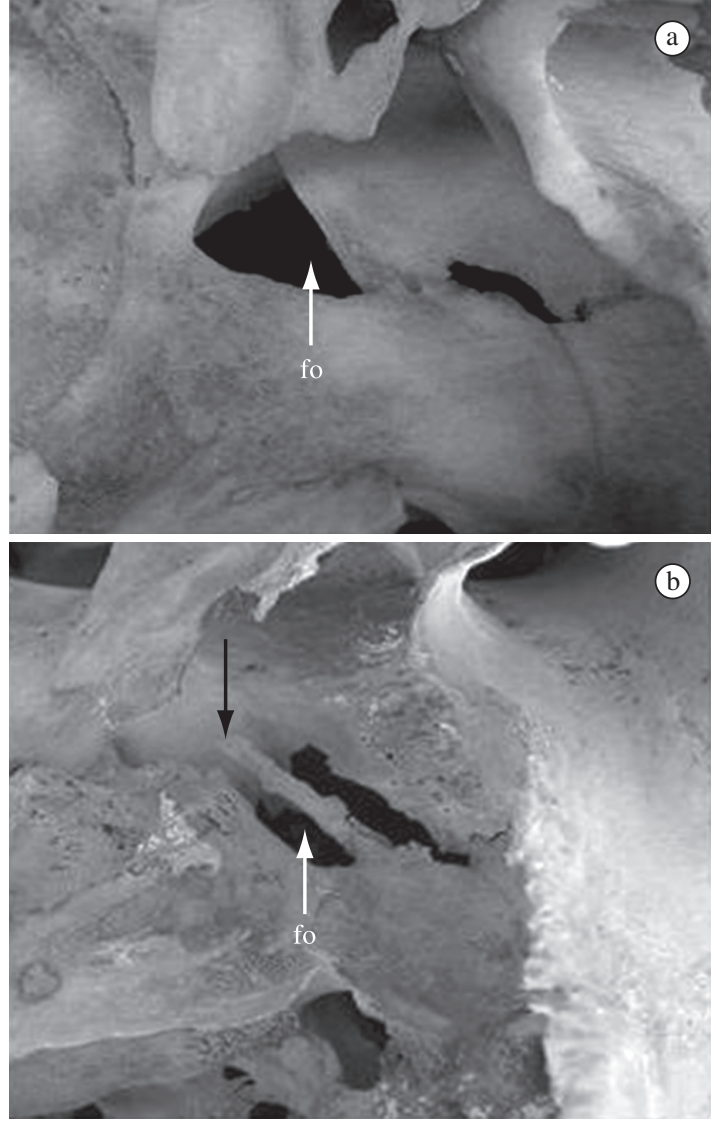

Figure 8. Shape of the anterior lacerate foramen (fo) observed in the genus Sotalia: a) open; and b) with spine form projection (black arrow).

in $100 \%$ of specimens of both species (except for INPA specimen 130 from AP, whose pterygoides had medial contact). In riverine species it was observed that generally there was a greater distance between pterygoids in the posterior portion, forming an inverted "v". Young individuals of marine species seems to present this same 
greater distance in the posterior portion. This could indicate neoteny in the riverine species, but in order to be able to interpret this variation a more thorough morphometric study is needed.

\subsection{Anterior lacerate foramen}

The predominant form of anterior lacerate foramen was distinct in the two species (Figures 8 and 9). In S. fluviatilis, the majority of specimens $(88 \%, \mathrm{n}=43)$ exhibited open/elongated anterior lacerate foramen. In $S$. guianensis, the majority of the specimens analysed exhibited foramen divided by a projection in the form of a spine: $72 \%(\mathrm{NOR}, \mathrm{n}=25), 77.5 \%(\mathrm{CE}, \mathrm{n}=40)$ and $98 \%$, $(\mathrm{SC}, \mathrm{n}=38)$. This spine projection, which rarely develops in adults of the riverine species, seems to be associated with ontogenetic development in the marine species, leading to the assumption that it is related to neoteny. A more detailed study with a larger number of young and juveniles of both species could provide an answer to this question. In the three marine samples analysed, it was observed that some individual adults exhibited a formation of fusion points between the projection and one side of the lacerate foramen.

\subsection{Hypoglossal foramen}

The location of hypoglossal foramen next to the jugular notch was considerably higher in S. guianensis: $88 \%(\mathrm{NOR}, \mathrm{n}=25), 95 \%(\mathrm{CE}, \mathrm{n}=41)$ and $98 \%(\mathrm{SC}$, $\mathrm{n}=39$ ). In this species, this foramen is generally visible in the ventral view, externally displaced to the jugular notch. Conversely, in the riverine species, the majority of specimens $(87 \%, \mathrm{n}=45)$ exhibited this foramen internally displaced to the jugular notch, not easily observed in the ventral view (Figures 10 and 11). It is worth noting, however, that variation exists in the proximity of this foramen to the jugular notch in both species, where some individuals exhibit a displaced foramen, being either separated or together with the notch. This characteristic doesn't seem to be related with development.

\subsection{Cervical vertebrae}

In the cervical vertebrae, projections on the seventh cervical vertebrae $\left(\mathrm{Ce}_{7}\right)$ associated with the transversal canal (= vertebrarterial canals), are called pleuroapophiseal plates or cervical ribs (Figures 12). The occurrence of these structures was higher in $S$. fluviatilis $(87 \% ; \mathrm{n}=31)$ than in $S$. guianensis from CE $(9 \%, \mathrm{n}=23)$

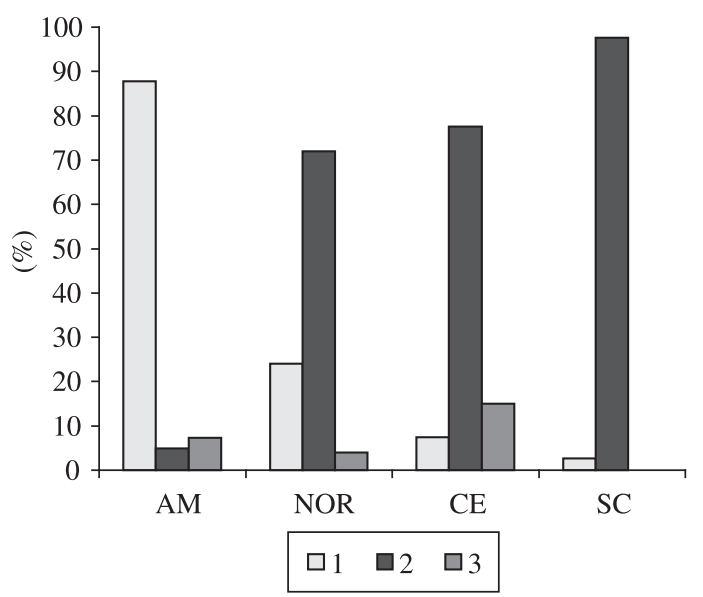

Figure 9. Variation of the anterior lacerate foramen shapes (fo) observed in the specimens of genus Sotalia: 1- open; 2- with projection spine form; 3- narrow or partially closed. AM- Amazonas, CE- Ceará, NOR (samples of AP and PA together), SC- Santa Catarina.
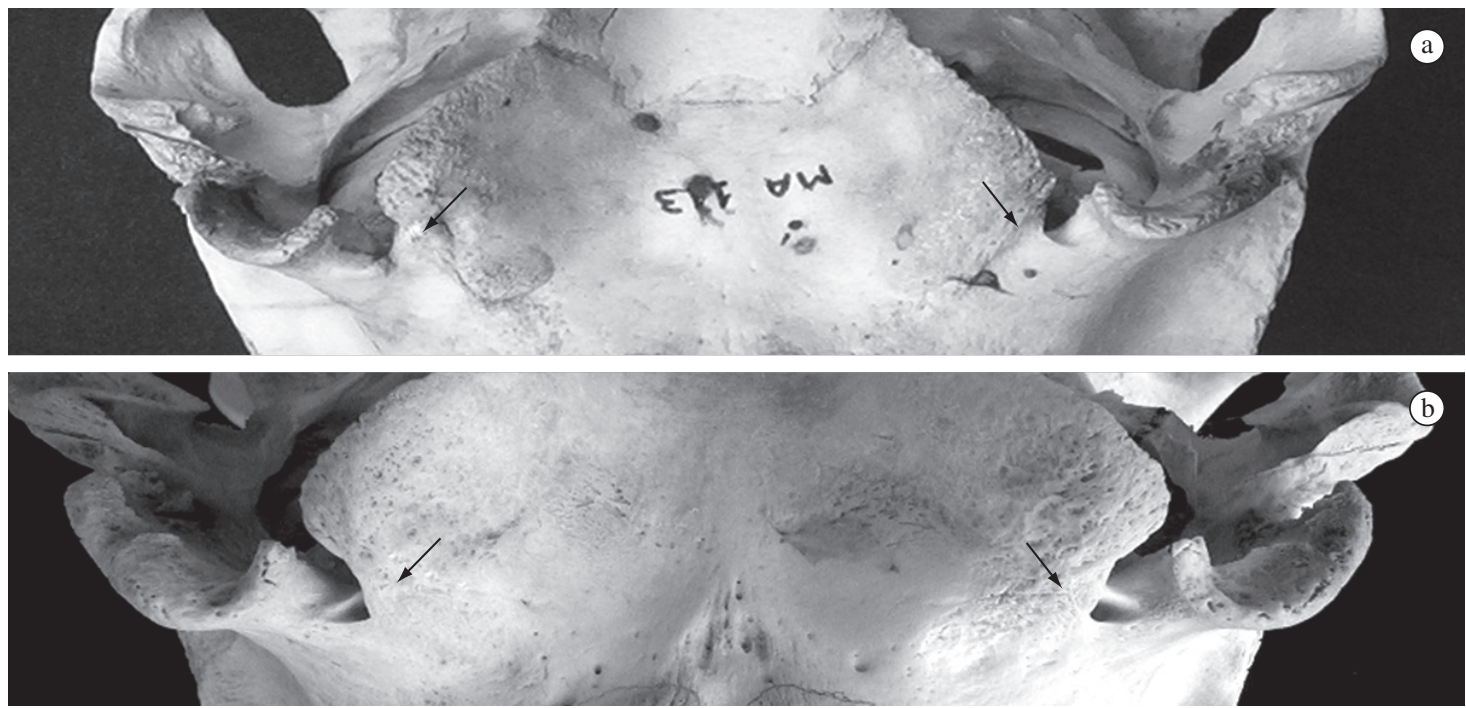

Figure 10. Localization of hipoglossal foramen in specimens of the genus Sotalia. a) Sotalia fluviatilis, the foramen cannot be observed in ventral view; b) Sotalia guianensis (SC), the foramen is dislocated externally to jugular notch and can be observed in ventral view. Structures indicated by the black arrows. 


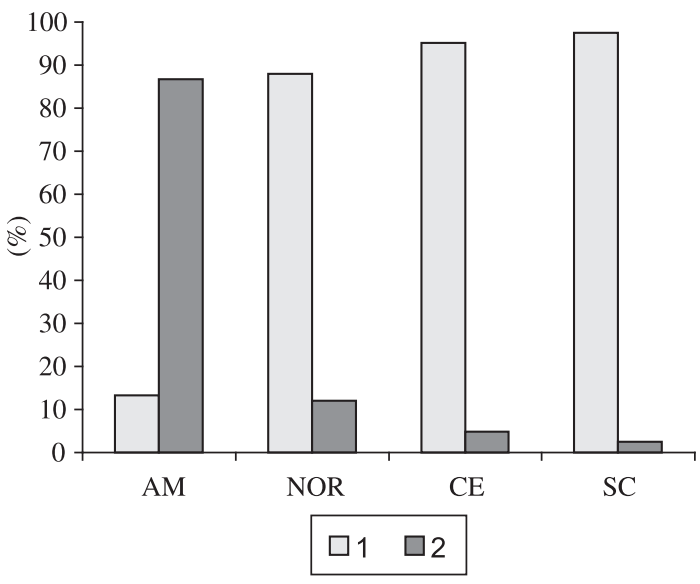

Figure 11. Percentage of the occurrence of hipoglossal foramen: 1- Hipoglossal foramen visible in ventral view; 2- Hipoglossal foramen not visible in ventral view. AMAmazonas, CE- Ceará, NOR (samples of AP and PA together), SC- Santa Catarina.
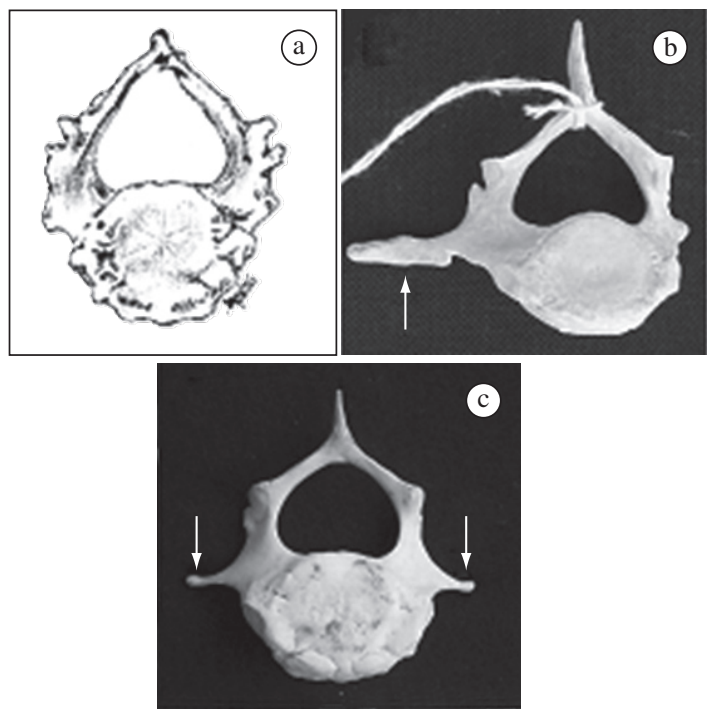

Figure 12. Cervical vertebrae from Sotalia. a) Seventh cervical vertebra (Ce7) of $S$. guianensis (normal); b) $\mathrm{Ce} 7$ of S. guianensis (CE) with cervical rib on lef side; c) Ce7 of S. fluviatilis (AM) with cervical rib in both sides. Structures indicated from arrows.

and from SC $(19 \%, n=32)$. Furthermore, the size of the ribs is proportionally smaller in the riverine species than in the marine species. In S. guianensis, the cervical ribs were generally observed only on one side (right or left), while in S. fluviatilis they were observed on both sides. The UFSC specimen 1117 exhibited this structure on the on the right side of the third cervical vertebra $\left(\mathrm{Ce}_{3}\right)$. The cervical ribs were observed in all age classes.

\section{Discussion}

\subsection{Fenestrae}

The presence of fenestrae commonly observed in the occipital region, near the condyles of Sotalia fluviatilis was also recorded in juveniles and adults of Pontoporia blainvillei (Gervais and d'Orbigny, 1844) (Pinedo,1991). However, in Pontoporia, the number of fenestrae was greater than that observed for the genus Sotalia.

In the genus Sotalia, the occurrence of fenestrae next to protuberances of the occipital region was low compared with the region next to the condyles. In the basioccipital, the presence of fenestrae was less frequent in immature specimens than in mature specimens. In Pontoporia blainvillei and in Stenella the occurrence of this structure was rare and occasional, respectively (Pinedo, 1991; Perrin et al., 1982).

Considering that the fenestrae observed next to the condyles in S. fluviatilis do not have the same origin as the fontanelles present in newborn individuals, given their different location, the origin and function of these fenestrae are not clear.

\subsection{Vomer}

The cranial floor is not generally included in morphologic studies and revealed interesting results. SimõesLopes (2006), analysing specimens of S. guianensis in the southern region, observed that the laminar posterior process of the vomer is narrower than the lamelar pterygoid processes.

In the same study, the author found the converse in S. fluviatilis - where the vomer is broader and the lamelar pterygoid processes narrower. In the present work we verified that this characteristic described by Simões-Lopes (2006) was present in the majority of the marine specimens analysed. However, in the samples from $\mathrm{CE}$ and $\mathrm{AP}$, we observed that some specimens also possessed a broad vomer, similar to the riverine species, herein called the "wide form". Apparently, this characteristic can be used to distinguish the two species, but it is important to note that a small percentage of marine specimens possess a broad vomer just as some riverine specimens possess a narrow vomer. Thus, the use of this characteristic should be considered in combination to others when separating the species.

In relation to the posterior alignment of the vomer, the arrangement anterior to the lamelars pterygoid processes was observed in $100 \%$ of the cases for the marine species. In the riverine species $(n=39), 18 \%$ were observed with the posterior edge of the vomer aligned with the pterygoids, while in another $18 \%$ the posterior edge of the vomer extended beyond the pterygoides. Dawbin et al. (1970) attribute the alignment of the vomer in relation to the posterior pterygoid processes to age. For these authors, in sub-adults Peponocephala electra (Gray, 1846) the vomer extends to the level of the sutures between the pterygoides and basioccipital and in adults, the vomer extends beyond the adjacent pterygoides. This 
pattern was not observed in the current study, since all adults of $S$. guianensis were observed with the posterior suture of the vomer anterior to the pterygoides. Moreover, the variation observed in the riverine species does not appear to be related to ontogenetic development, but rather to individual variation.

\subsection{Pterygoides}

The pterygoides were found to be medially separated by a projection in the tip of the palatines in all specimens, corroborating the data found in the literature (van Bénéden, 1875; Flower, 1885; Miranda-Ribeiro, 1936, da Silva and Best, 1994; 1996; Avila et al., 2002; SimõesLopes, 2006). The variation in the form of the posterior projection of the left pterygoide was very subtle between the two species.

\subsection{Anterior lacerate foramen}

The anterior lacerate foramen is formed by two foramens (the optic foramen and the orbitorotundum foramen). These two structures are divided by a "wall" (Yamagiwa, et al., 1999) here called a spike-shaped projection. In S. guianensis, the majority of the adult specimens (between 72 and 98\%) exhibited this projection between the optic and the orbitorotundum foramen. On the other hand, the narrow form was only observed in adults, suggesting that with time, this spiny projection fused with one side of the lacerated foramen (as observed in some marine specimens). In S. fluviatilis, in contrast, the absence of this projection was more common (88\%), and could indicate neoteny.

\subsection{Hypoglossal foramen}

The location of the hypoglossal foramen varied between the two species. In S. guianensis the hypoglossal foramen generally meets between the crest of the basioccipital and the paraoccipital process, more precisely in the jugular notch as it occurs in other species of marine Delphinidae, for example, Grampus griseus (Cuvier, 1812) (Yamagiwa et al., 1999) and Tursiops truncatus (Montagu, 1821) (Rommel, 1990). In contrast, the hypoglossal foramen in S. fluviatilis, in the majority of cases, was found to be internally displaced.

\subsection{Cervical vertebrae}

The occurrence of cervical ribs was higher $(87 \%)$ in the riverine species. The presence of pleuroapophiseal plates was initially suggested for some groups of mammals, especially monotremes and marsupials (Lessertisseur and Saban, 1967). Unilateral or bilateral processes in the cervical vertebrae are common in some groups of mammals (including Homo), and the costal rudiments are associated with the vertebral or vertebrarterial foramens (Lessertisseur and Saban, 1967). These authors also mention their presence in marine mammals as Orcinus orca (Linnaeus, 1758), Tursiops truncatus and Balaenoptera sp. Such processes have been considered serially homologous to the cervical ribs, also appearing in the literature as costal plates or pleuroapophiseal plates
(Flower and Lyddeker, 1891). The presence of cervical ribs is an intriguing characteristic in comparative anatomy, as these structures are typically observed in reptiles (Paula Couto, 1979; Ferigolo, 1987). In S. guianensis, these structures have already been reported in about $22.5 \%(\mathrm{n}=31)$ of the specimens of the southern region (Fettuccia and Simões-Lopes, 2004). In this work, considering a larger sample, the observed frequency of cervical ribs in the specimens from SC was $19 \%(\mathrm{n}=33)$, and of $9 \%(n=23)$ from CE. Cervical ribs in mammals are examples of atavism (reappearance of an extinct character, common to ancestral lineages that rarely occur in current populations). Other cases of atavism are described in the literature as the occurrence of vestigial posterior members in whales and extra-numeric teeth in bats and sea lions (Bejder and Hall, 2002; Rui and Drehmer, 2004 and Drehmer et al., 2004). According to Hall (1984), there are four basic criteria for the recognition of an atavism: 1) persistence of the characteristic in adult life; 2) absence of this characteristic in the parents or recent ancestors; 3 ) occurrence in one or a few individuals within a population; and 4) similarity or identity with the same character exhibited by all the members of the ancestral population. Moreover, if the incidence of the character is still relatively high in a population, it is considered a polymorphism (Hall, 1984). Thus, considering the high occurrence of cervical ribs in specimens of the riverine species, these structures do not appear to be atavistic, suggesting the need for a more detailed study with a more representative sample number for a more consistent conclusion.

Acknowledgements - The authors would like to thank Angel Enzo Crovetto, César Drehmer, Fernando Rosas, Lena Geise and two anonymous referees for their helpful suggestions on improving the manuscript. We would also like to thank Nina Best for the English review. Special thanks to the Museu Paraense Emilio Goeldi (MPEG) and Associação de Pesquisa e Preservação de Ecossistemas Aquáticos (AQUASIS). This work was supported by grants from CNPq and IEB.

\section{References}

ALVES-JÚNIOR, TT. and MONTEIRO-NETO, C., 1999. Caracterização morfológica e morfométrica craniana do botocinza, Sotalia fluviatilis Gervais, 1953, da Costa do Ceará, Brasil. Arquivos de Ciências do Mar, no. 32, p. 89-101

ÁVILA, FJC., ALVES-JÚNIOR, TT., PARENTE, CL., VAZ, LAL. and MONTEIRO-NETO, C., 2002. Osteologia do botocinza, Sotalia fluviatilis Gervais, 1853, da Costa do Estado do Ceará, Brasil. Arquivos de Ciências do Mar, no. 35, p. $145-155$.

BEJDER, L. and HALL, BK., 2002. Limbs in whales and limblessness in other vertebrates: mechanisms of evolutionary and developmental transformation and loss. Evolution and Development, vol. 4, no. 6, p. 445-458.

VAN BÉNÉDEN, E., 1875. Mémoire sur un dauphin nouveau de la Baie de Rio de Janeiro, désigné sous le nom de Sotalia brasiliensis. Memmoires de l'Academie Royale de Sciences Belgique, vol. 41, p. 2-44. 
BOROBIA, M., 1989. Distribution and morphometrics of South American dolphins of the genus Sotalia. Montreal: McDonald College of McGill University. 81 p. [Master's thesis].

BOROBIA, M., SICILIANO, S., LODI, L. and HOEK, W., 1991. Distribution of the South American dolphin Sotalia fluviatilis. Canadian Journal Zoology, no.69, p. 1025-1039. CASINOS, A., BISBAL, F. and BOHER, S., 1981. Sobre três exemplares de Sotalia fluviatilis del Lago Maracaibo (Venezuela) (Cetacea, Delphinidae). Proceedings of the Departament of Zoology, no. 7, p. 93-96.

CUNHA, HA., DA SILVA, VMF., LAILSON-BRITO Jr, J., SANTOS, MCO., FLORES, PAC., MARTIN, AR. et al., 2005. Riverine and marine ecotypes of Sotalia dolphins are different species. Marine Biology, vol. 148, no. 2, p. 449-457.

CABALLERO, S., TRUJILLO, F., VIANNA, JA., BARRIOSGARRIDO, H., MONTIEL, MG., BELTRÁN-PEDREROS, S. et al., 2007. Taxonomic status of the genus Sotalia: species level ranking for "tucuxi" (Sotalia fluviatilis) and "costero" (Sotalia guianensis) dolphins. Marine Mammal Science, vol. 23, no. 2, p. $358-386$.

DA SILVA, VMF. and BEST, RC., 1994. Tucuxi Sotalia fluviatilis (Gervais, 1853). In RIDGWAY, SH., HARRISON, SR. (Eds). Handbook of Marine Mammals. London: Academic Press. p. 43-69. p. 1-7.

, 1996. Sotalia fluviatilis. Mammalian Species, no. 527,

DAWBIN, WH., NOBLE, BA. and FRASER, FC., 1970. Observations on the electra dolphin, Peponocephala electra. Bulletin of the British Museum (Natural History), vol. 20, no. 6, p. 173-201.

DREHMER, CJ., FABIÁN, ME. and MENEGHETI, JO., 2004. Dental anomalies in the Atantic population of South American sea lion, Otaria byronia (Pinnipedia, Otariidae): evolutionary implications and ecological approach. LAJAM, vol. 3, no. 1, p. 7-18.

FERIGOLO, J., 1987. Anatomia comparada, paleontologia e paleopatologia de vertebrados. Paula-Coutiana, no. 1, p. $105-127$.

FETTUCCIA, DC. and SIMÕES-LOPES, PC., 2004. Morfologia da coluna vertebral do boto-cinza, Sotalia guianensis (Cetacea, Delphinidae). Biotemas, vol. 17, no. 2, p. 125-148.

FLOWER, WH., 1885. An Introduction to the Osteology of the Mammalia. 3 ed. London: Macmillan \& Co. 344 p.

FLOWER, WH. and LIDEKKER, R., 1891. An introdution to the study of Mammals living and extinct. New York: Arno Press. 763 p. (Reprint edition 1978).
HALL, BK., 1984. Developmental echanisms underlying the formation of atavisms. Biological Reviews of the Cambridge Philosophical Society, no. 78, p. 409-433.

KRAGLIEVICH, L., 1937. Manual de Paleontologia Rio Platense Comparada de los Mamíferos. Montevideo: Ed. Siglo Ilustrado. $190 \mathrm{p}$.

LESSERTIEUR, J. and SABAN, R., 1967. Squelette Axial. In GRASSÉ, PP. (Ed.).Traité de Zoologie, Mammifères: Tèguments et Squelettes. Paris: Masson et Cie. Èditeurs. p. 585-708.

MENEZES, ME. and SIMÕES-LOPES, PC., 1996. Osteologia e morfologia da aleta peitoral da forma marinha de Sotalia fluviatilis (Cetacea-Delphinidae) no litoral do Brasil. Estudos de Biologia, vol. 4, no. 40, p. 23-31.

MIRANDA-RIBEIRO, A., 1936. Notas cetológicas dos gêneros Steno, Sotalia e Stenopontistes. Boletim do Museu Nacional do Rio de Janeiro, no. 12, p. 3-23.

MONTEIRO-FILHO, ELA., MONTEIRO, LR. and REIS, SF., 2002. Skull shape and divergence in dolphins of the genus Sotalia: a tridimensional morphometric analysis. Journal of Mammalogy, vol. 83, no. 1, p. 125-134.

PAUlA COUTO, C., 1979. Tratado de Paleomastozoologia. Rio de Janeiro: Academia Brasileira de Ciências. 590 p.

PERRIN, WF., YABLOKOV, AV. and CASS, VL., 1982. Preliminary report on the use of non-metrical skull characters to discriminate populations of pelagic dolphins. E.U.A.: National Marine Fisheries Services. 32 p.

PINEDO, MC., 1991. Development and variation of the franciscana, (Pontoporia blainvillei), Santa Cruz. California: University of California. 406 p. [PhD. Thesis].

ROMMEL, SA., 1990. Osteology of the Bottlenose Dolphin. In LEATHERWOOD, S.; REEVES, R. (Eds.). The Bottlenose Dolphin. San Diego: Academic Press. p. 29-49.

RUI, AM. and DREHMER, CJ., 2004. Anomalias e variações na fórmula dentária em morcegos do gênero Artibeus Leach (Chiroptera, Phyllostomidae). Revista Brasileira de Zoologia, vol. 21 , no. 3 , p. 639-648.

SIMÕES-LOPES, PC., 1988. Ocorrência de uma população de Sotalia fluviatilis (Gervais, 1853) (Cetacea, Delphinidae) no limite sul de sua distribuição, Santa Catarina, Brasil. Biotemas, vol. 1, no. 1, p. 57-62.

, 2006. Morfologia do sincrânio do Boto-cinza, Sotalia guianensis (P.J. van Bénédén, 1864) (Cetacea, Delphinidae). Revista Brasileira de Zoologia, vol. 23, no. 3, p. 652-660.

YAMAGIWA, D., ENDO, H., NAKANISHI, I., KUSANAGI, A., KUROHMARU, M. and HAYASHI, Y., 1999. Anatomy of the cranial nerve foramina in the Risso's dolphin (Grampus griseus). Annals of Anatomy, vol. 181, p. 293-297. 